1. Boiko, M.G., Hopkalo, L.M. Organization of the hotel industry: a textbook, Nat. Trading Econ. Univ., 2006.

2. Klochkov, A. KPI and staff motivation: a complete collection of practical tools, 2010.

3. Krul, H.Ya., and V.P. Rudenko. Fundamentals of Hotel Business, Center of Training Literature, 2011.

4. Kudriavtsev, V.D., Arzumanian, M.Yu., and L.Yu. Grigoriev. Business Engineering Technologies, Polytechnic University Publishing House, 2014.

5. Malska, M.P., and I.H. Pandiak. Hotel Business: Theory and Practice: Textbook, Center of Training Literature, 2012.

6. Ostapchuk, Yu. "The role of electronic communication in the information society." Visnyk Knyzhkovoi Palaty, no. 5, 2016, pp. 38-40.

7. Puntsentailo, P.R. Economy and organization of tourist and hotel enterprise, Center of Training Literature, 2007.

8. Roglev, H.Y. Fundamentals of Hotel Management: Textbook, Condor, 2009.

УДК 336.6: 352/354

doi: 10.15330/apred.1.15.58-68

\title{
УПРАВЛІННЯ ІНВЕСТИЦІЙНОЮ ДІЯЛЬНІСТЮ В УМОВАХ ДЕЦЕНТРАЛІЗАЦІї
}

\author{
ДВНЗ “Прикарпатський національний \\ університет імені Василя Стефаника", \\ Міністерство освіти і науки України, \\ кафедра теоретичної і прикладної економіки, \\ вул. Шевченка, 57, м. Івано-Франківськ, \\ 76018, Україна, \\ тел.: 0979040894, \\ e-mail: olaif2005@gmail.com
}

Анотація. Ефективна інвестиційна діяльність господарюючого суб'єкта є платформою для успішного розвитку не лише мікрорівня, а й макрорівня.

Менеджмент інвестиційної діяльності часто визначають вектори як державної так i регіональної та галузевої стратегії розвитку.

Додатній темп економічного зростання ВВП є ключовим чинником, що впливає на рішення суб'єктів господарювання щодо здійснення інвестування.

Проведено аналіз динаміки номінального ВВП України та визначено тенденції до його зростання, визначено темпи приросту ВВП за 2005-2018 pр., розраховано частку валового нагромадження у структурі ВВП. Аналіз цифрової інформації дозволяє нам зробити висновки, про те, що номінальний ВВП має тенденцію до зростання, проте частка валового нагромадження у ВВП коливається від 14,1 \% до 28,2\% протягом аналізованого періоду.

Це дасть змогу прийняття стратегічне рішення щодо управління інвестиційною діяльністю в умовах децентралізації. Управління інвестиційною діяльністю варто розмежувати на макро- та мікрорівнях. Нами встановлено, що ефективність даної діяльності прямо залежить від сприятливого інвестиційного клімату та макроекономічного регулювання, а також довгострокового та короткострокового періодів ії здійснення.

Стан інвестиційної діяльності господарюючого суб’єкта можна визначити за допомогою алгоритму: оцінювання інвестиційної стратегії; визначення привабливих напрямків для ефективного вкладення капіталу з метою сталого розвитку підприємств, зважування вартості джерел інвестиційних ресурсів; вибір розрахунку ризику та ефективності інвестиційних проектів; оперативному виявленню чинників, які впливають на відхилення фактичних 
результатів інвестування від запланованих; визначення міри досягнення цільових показників після впровадження інвестиційних проектів, а також можливих резервів покращення результатів.

Варто погодитись, що важливими чинниками інвестиційної привабливості в Україні $є$ : низький рівень корупції, прозорі та чітко визначені законодавча та нормативна бази, політична стабільність.

При інвестуванні керівництво кожного підприємства зобов'язане вирішувати завдання щодо розробки інвестиційної стратегії підприємства, вибирати форми та об'єкти інвестування, шукати джерела фінансування, вибирати інвесторів та учасників інвестиційного процесу, розробляти, аналізувати та оцінювати інвестиційні проекти, здійснювати контроль за результатами інвестиційної діяльності.

Перспективними завданнями управління інвестиційною діяльністю підприємства повинні стати: максимізувати інвестиційний прибуток господарюючого суб'єкта; мінімізувати інвестиційний ризик суб'єкта господарювання; знайти напрями покращення інвестиційних процесів.

Виявлено галузеві особливості управління інвестиційною діяльністю на господарюючого суб'єкта. За рахунок покращення інформаційної забезпеченості, стратегічного планування, оцінки організації, посилення контролю, постійного моніторингу інвестиційних проектів, здійснення фінансово-економічних розрахунків можна досягнути високої ефективності управління інвестиційною діяльністю господарюючого суб'єкта.

Маючи чітку організацію процесу управління інвестиційною діяльністю господарюючого суб'єкта можна стверджувати про систему іiі ефективного функціонування в умовах децентралізації.

Ключові слова: управління інвестиційною діяльністю, господарюючий суб'єкт, менеджмент, інвестиційна стратегія підприємства, стратегічне планування інвестиційної діяльності.

\title{
MANAGEMENT OF INVESTMENT ACTIVITY IN CONDITIONS OF DECENTRALIZATION
}

Yemets O.I.

\author{
Vasyl Stefanyk Precarpathian National University \\ Ministry of Education and Science of Ukraine, \\ Department of Theoretical and Applied \\ Economics, \\ st. Shevchenko, 57, Ivano-Frankivsk, \\ 76018. Ukraine, \\ tel.: 0979040894, \\ e-mail olaif2005@gmail.com
}

\begin{abstract}
Effective investment activity of the business entity is a platform for the successful development of not only the micro level, but also the macro level.

Management of investment activity is often determined by state, regional and sectoral development strategies. to invest.

The pace of economic growth (GDP) is a key factor that affecs the decision of economic entities

An analysis of the dynamics of the nominal GDP of Ukraine was made and trends in its growth were determined, GDP growth rates for the period from 2005 to 2018 were determined, the share of gross accumulation in the GDP structure was calculated. The analysis of this information allows us to conclude that nominal GDP has a tendency to increase, but the share of gross accumulation in GDP ranges from $14.1 \%$ to $28.2 \%$ over the analyzed period.

This will make it possible to make a strategic decision on managing investment activities in a decentralized environment. Management of investment activity should be distinguished at macro and micro levels. We have found that the effectiveness of such kind of activity directly depends on the
\end{abstract}


favorable investment climate and macroeconomic regulation, as well as the long-term and short-term periods of its implementation.

Conditions of investment activity of the economic entity can be determined by using the next algorithm: assessment of the investment strategy; determination the most attractive ways of profitable capital investments for providing sustainable development of enterprises; valuation of investment resources; risk and efficiency calculation of investment projects; Identification of factors that influence the deviation of the actual results of the investment activity from the planned; assessment of the achieving the target indicators after the realization of investment projects as well as assessment of possible reserves to improve the results.

One should agree that important factors of investment attractiveness in Ukraine are: low level of corruption, transparent and clearly defined legislative and regulatory frameworks and political stability.

When investing, the management of each enterprise is obliged to develop the investment strategy of the enterprise, choose the forms and objects of investment, search for sources of financing, choose investors and participants of the investment process, develop, analyze and evaluate investment projects, control the results of investment activity.

The main tasks of management of investment activity of an enterprise should be: maximizing the investment profit; minimizing the investment risk; finding ways to improve investment processes.

Influence of the industry features of management of investment activity on the business entity are revealed.

By improving information security, strategic planning, evaluation of organization, control, regular monitoring of investment projects and implementation of financial and economic calculations, it is possible to achieve high efficiency of management of the investment activity of the business entity.

Having a clear organization of the process of managing the investment activity of the economic entity can be argued about the system of its effective functioning in conditions of decentralization.

Key words: management of investment activity, economic entity, management, investment strategy of the enterprise, strategic planning of investment activity.

Вступ. Інвестиційна діяльність підприємства є сегментом фінансової стратегії, яка реалізується через вибір і впровадження найбільш ефективних напрямів збільшення активів підприємства 3 метою забезпечення основних шляхів його розвитку. Управління інвестиційною діяльністю необхідно для формування перспективного стану економіки в умовах децентралізації. Адже завдяки достатнім обсягам інвестицій у процес виробництва, забезпеченні прибутковості й терміновості досягнення цілей, розробці стратегій інвестиційної діяльності, аналізі економічного стану підприємства та доцільності залучення інвестицій. Для визначення стану інвестиційної діяльності підприємств необхідно дотримуватись певного алгоритму: оцінювання інвестиційної стратегії; визначення привабливих напрямків для ефективного вкладення капіталу 3 метою сталого розвитку підприємств, зважування вартості джерел інвестиційних ресурсів; вибір розрахунку ризику та ефективності інвестиційних проектів; оперативному виявленню чинників, які впливають на відхилення фактичних результатів інвестування від запланованих; визначення міри досягнення цільових показників після впровадження інвестиційних проектів, а також можливих резервів покращення результатів. Квінтесенція інвестиційної діяльності підприємств розглядається як комплексний процес, що об'єднує окремі логічно пов'язані етапи, кожний $з$ яких складається $з$ сукупності показників оцінки інвестиційної діяльності підприємств, на основі яких робиться висновок про можливість переходу до іншого етапу. Погоджуємось із думкою, яка висвітлена в [1, С. 55] про те, що головними чинниками національної інвестиційної привабливості $є$ :

низький рівень корупції (79,8\%),

прозорі та чітко визначені законодавча та нормативна бази (70,2\%), 
політична стабільність (69,2\%).

Постановка проблеми. У сучасних умовах децентралізації управління інвестиційною діяльністю, на нашу думку, $\epsilon$ найважливішим елементом загальної системи управління. Незважаючи на множинність наукових розробок, національний економічний механізм інвестиційної політики вимагає обгрунтування та методичної розробки. В умовах ринкової економічної системи пріоритетними векторами його вдосконалення мають стати: активізація інвестиційних процесів відповідно до визначених пріоритетів, посилення відповідальності за ефективність прийнятих рішень у сфері державного інвестування, оптимальне використання ресурсів в інтересах здійснення пріоритетних інвестицій, створення взаємовигідного механізму залучення тимчасово вільних коштів у глобальні процеси.

При вирішенні поставлених завдань нами використано ряд методів дослідження: методи статистичного аналізу - для оцінки стану та динаміки ВВП, частки валового нагромадження; а також методи аналізу та синтезу, порівняльних характеристик щодо проблем управління інвестиційною діяльністю.

Метою статті $є$ проаналізувати динаміку номінального ВВП України у національній та іноземній валюті, визначити темпи приросту ВВП за 2005-2018 рр., розрахувати частку валового нагромадження у структурі ВВП з метою прийняття стратегічних рішень щодо управління інвестиційною діяльністю в умовах децентралізації.

Результати. У сучасній ринковій економічній системі все більше менеджерів пріоритетного значення надають розробці перспективних напрямів інвестиційної діяльності підприємства, ефективним інструментом чого є стратегічне планування. Складність стратегічного планування інвестиційної діяльності зумовлена довгостроковим періодом його здійснення й високою мірою непередбачуваності реалістичності планових рішень, що виникає звідси. Ефективним інструментом перспективного управління інвестиційною діяльністю підприємств в умовах коливання макроекономічних показників, кон'юнктури інвестиційного ринку та пов'язаною з цим невизначеністю виступає інвестиційна стратегія. Під нею будемо розуміти систему довгострокових цілей інвестиційної діяльності господарюючого суб'єкта, що визначаються загальними цілями його розвитку, а також вибір найефективніших шляхів для їх досягнення.

Інвестиційну стратегію можна презентувати як генеральний напрямок інвестиційної діяльності підприємства, проходження яким в довгостроковому періоді призведе до досягнення інвестиційних цілей і отримання очікуваного інвестиційного ефекту. Інвестиційна стратегія підприємства визначає головні перспективні форми i напрями інвестиційної діяльності, способи формування інвестиційних ресурсів i алгоритм реалізацій інвестиційних цілей у довгостроковому періоді, що забезпечують прогнозований розвиток підприємства.

Основними елементами процесу розробки інвестиційної стратегії підприємства $є$ : місія, цілі розвитку, система стратегій в розрізі видів діяльності, характер формування та розподілу ресурсів. Дотримуючись меж інвестиційної програми, необхідно здійснювати відбір інвестиційних проектів ще на стадії планування, для того щоб мінімізувати ризики.

Вибір об'єкту реального інвестування $є$ одним 3 найбільш відповідальних моментів для управління інвестиціями. Адже інвестиційний проект $є$ складовою частинкою управління інвестиціями, який реалізовується на основі оцінювання їх ефективності. Ефективність інвестиційних проектів, в умовах формування ринкової економічної системи, визначають $з$ дотриманням наступних принципів:

оцінки повернення інвестованого капіталу, на базі показника грошового потоку; 
приведення до теперішньої вартості інвестованого капіталу, і суми грошового потоку;

вибору диференційованої дисконтної ставки (індивідуальна норма прибутковості, середньозважена вартість капіталу, середня депозитна або кредитна ставки);

співставлення обсягу інвестиційних витрат та їх сум із строком повернення інвестованого капіталу із врахуванням факторів ризику та інфляції.

При врахуванні цих принципів можна сформувати методи для оцінки ефективності інвестиційних проектів.

Кінцевий вибір критерію визначення доцільності інвестицій різних суб'єктів господарювання залежить від економічної ситуації в країні, інвестиційного клімату, пріоритетів та політики підприємства.

У праці. [2, С. 186] нами запропоновано розглянути сучасні підходи до управління інвестиційною діяльністю на двох головних рівнях: макроекономічному та мікроекономічному.

Управління інвестиційною діяльністю на макроекономічному рівні, тобто державне, спрямоване, на створення сприятливих умов для здійснення інвестиційної діяльності різними суб'єктами господарювання на певній території (держава, регіон).

Для цього варто визначити частку валового нагромадження у структурі ВВП України, розрахованому методом кінцевого використання з 2005 по 2017 рр. (табл. 1).

ВВП України за 2005-2017 рр., млн. грн.

Таблиия 1

GDP of Ukraine for 2005-2017, mln.

Table 1

\begin{tabular}{|c|c|c|c|}
\hline Роки & $\begin{array}{c}\text { Номінальний ВВП, млн. } \\
\text { грн. }\end{array}$ & $\begin{array}{c}\text { Валове нагромадження, млн. } \\
\text { грн. }\end{array}$ & \% ВВП \\
\hline 2005 & 441452 & 99876 & 22.6 \\
\hline 2006 & 544153 & 134740 & 24.8 \\
\hline 2007 & 720731 & 203318 & 28.2 \\
\hline 2008 & 948056 & 264883 & 27.9 \\
\hline 2009 & 913345 & 155815 & 17.1 \\
\hline 2010 & 1082569 & 199918 & 18.5 \\
\hline 2011 & 1316600 & 282474 & 21.5 \\
\hline 2012 & 1408889 & 257335 & 18.3 \\
\hline 2013 & 1454931 & 228474 & 15.7 \\
\hline 2014 & 1566728 & 220968 & 14.1 \\
\hline 2015 & 1979458 & 303297 & 15.3 \\
\hline 2016 & 2383182 & 512830 & 21.5 \\
\hline 2017 & 2982920 & 618914 & 20.7 \\
\hline
\end{tabular}

Джерело[3]

Валове нагромадження основного капіталу - це приріст нефінансових активів, які протягом тривалого часу використовуються в процесі виробництва. Величина валового нагромадження основного капіталу оцінюється виходячи із загальної вартості основних засобів, придбаних інституційними одиницями (за винятком реалізованих) у звітному періоді, а також збільшення невироблених активів, що відбулося в результаті продуктивної діяльності інституційних одиниць [4].

Аналіз цифрової інформації, представленої у таблиці 1 дозволяє зробити висновок, що номінальний ВВП має тенденцію до зростання, проте частка валового 
нагромадження у ВВП коливається протягом аналізованого періоду , що продемонстровано на рис.1.

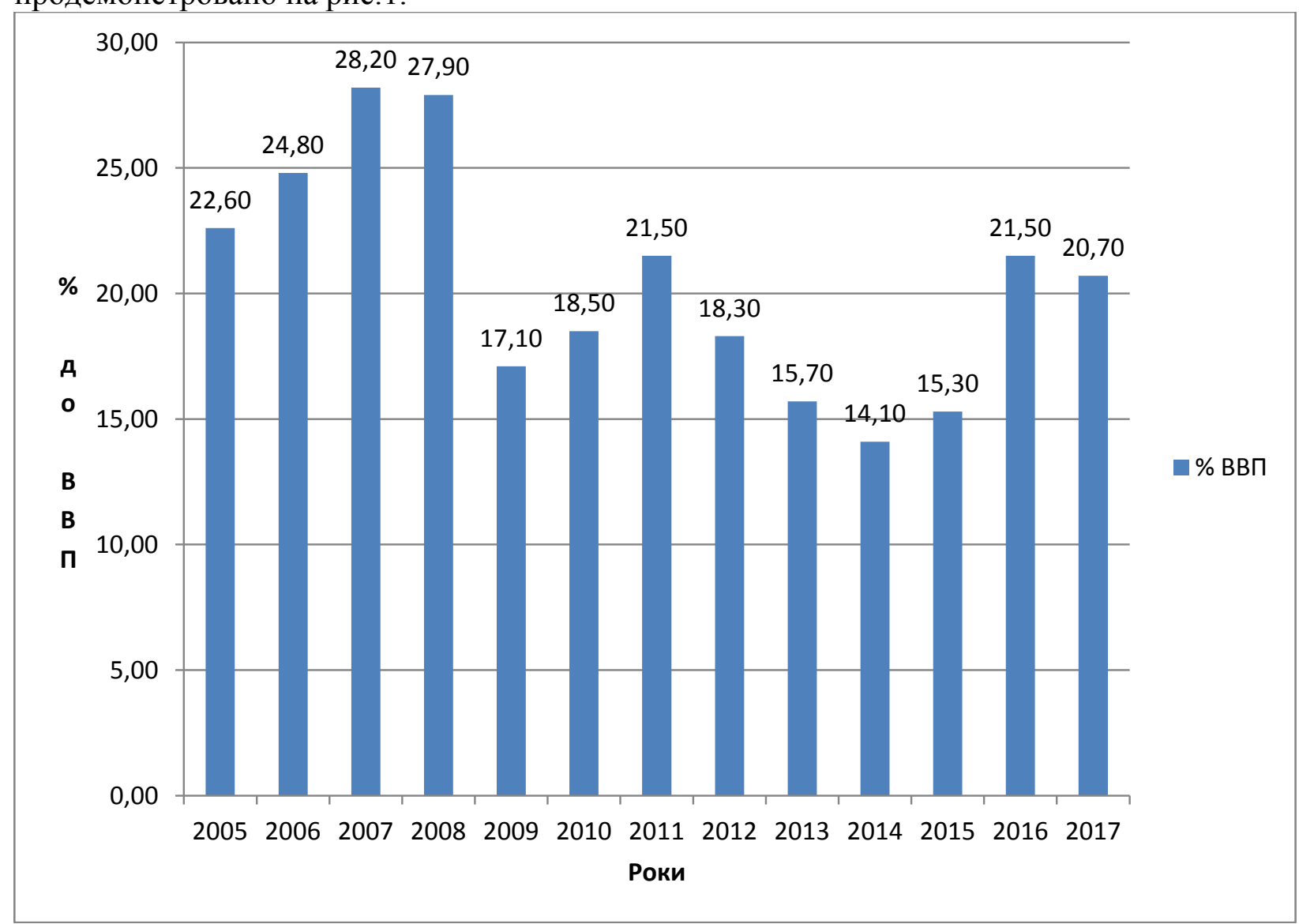

Puc.1. Динаміка валового нагромадження в Україні, \% до ВВП у 2005-2017 pp.

Fig. 1. Gross accumulation dynamics in Ukraine, \% of GDP in 2005-2017

Нестійка тенденція щодо темпу приросту номінального ВВП України за 20052017 рр. у національній та іноземній валюті представлена у таблиці 2. 
Номінальний ВВП України за 2005-2017 рр.

Таблиця 2

Nominal GDP of Ukraine for 2005-2017

Table 2

\begin{tabular}{|c|c|c|c|c|c|c|}
\hline Роки & $\begin{array}{c}\text { Номі- } \\
\text { нальний } \\
\text { ВВП, млн. } \\
\text { грн. }\end{array}$ & $\begin{array}{c}\text { Абсолютний } \\
\text { приріст, млн. } \\
\text { грн. }\end{array}$ & $\begin{array}{c}\text { Темп } \\
\text { приросту, } \\
\text { \% }\end{array}$ & $\begin{array}{c}\text { Номі- } \\
\text { нальний } \\
\text { ВВП, млн. } \\
\text { дол. США }\end{array}$ & $\begin{array}{c}\text { Абсолютний } \\
\text { приріст, Млн. } \\
\text { дол. США }\end{array}$ & $\begin{array}{c}\text { Темп } \\
\text { приросту, } \\
\%\end{array}$ \\
\hline $\mathbf{2 0 0 5}$ & 441452 & 96339 & $27.9 \%$ & 86142 & 21259 & $32.8 \%$ \\
\hline $\mathbf{2 0 0 6}$ & 544153 & 102701 & $23.3 \%$ & 107753 & 21611 & $25.1 \%$ \\
\hline $\mathbf{2 0 0 7}$ & 720731 & 176578 & $32.5 \%$ & 142719 & 34966 & $32.5 \%$ \\
\hline $\mathbf{2 0 0 8}$ & 948056 & 227325 & $31.5 \%$ & 179992 & 37273 & $26.1 \%$ \\
\hline $\mathbf{2 0 0 9}$ & 913345 & -34711 & $-3.7 \%$ & 117228 & -62765 & $-34.9 \%$ \\
\hline $\mathbf{2 0 1 0}$ & 1082569 & 169224 & $18.5 \%$ & 136419 & 19192 & $16.4 \%$ \\
\hline $\mathbf{2 0 1 1}$ & 1316600 & 234031 & $21.6 \%$ & 163160 & 26740 & $19.6 \%$ \\
\hline $\mathbf{2 0 1 2}$ & 1408889 & 92289 & $7.0 \%$ & 175781 & 12622 & $7.7 \%$ \\
\hline $\mathbf{2 0 1 3}$ & 1454931 & 46042 & $3.3 \%$ & 183310 & 7529 & $4.3 \%$ \\
\hline $\mathbf{2 0 1 4}$ & 1566728 & 111797 & $7.7 \%$ & 131805 & -51505 & $-28.1 \%$ \\
\hline $\mathbf{2 0 1 5}$ & 1979458 & 412730 & $26.3 \%$ & 90615 & -41190 & $-31.3 \%$ \\
\hline $\mathbf{2 0 1 6}$ & 2383182 & 403724 & $20.4 \%$ & 93270 & 2655 & $2.9 \%$ \\
\hline $\mathbf{2 0 1 7}$ & 2982920 & 599738 & $25.2 \%$ & 112154 & 18884 & $20.2 \%$ \\
\hline
\end{tabular}

Джерело [5]

На рисунку 2 наочно відображено темпи приросту ВВП протягом досліджуваного нами періоду. Особливого пояснення потребують 2014 р. та 2015 р., адже темп приросту номінального ВВП у національній грошовій одиниці є додатним, а темп приросту номінального ВВП у іноземній валюті має від'ємне значення, що пояснюється зростанням валютного курсу.

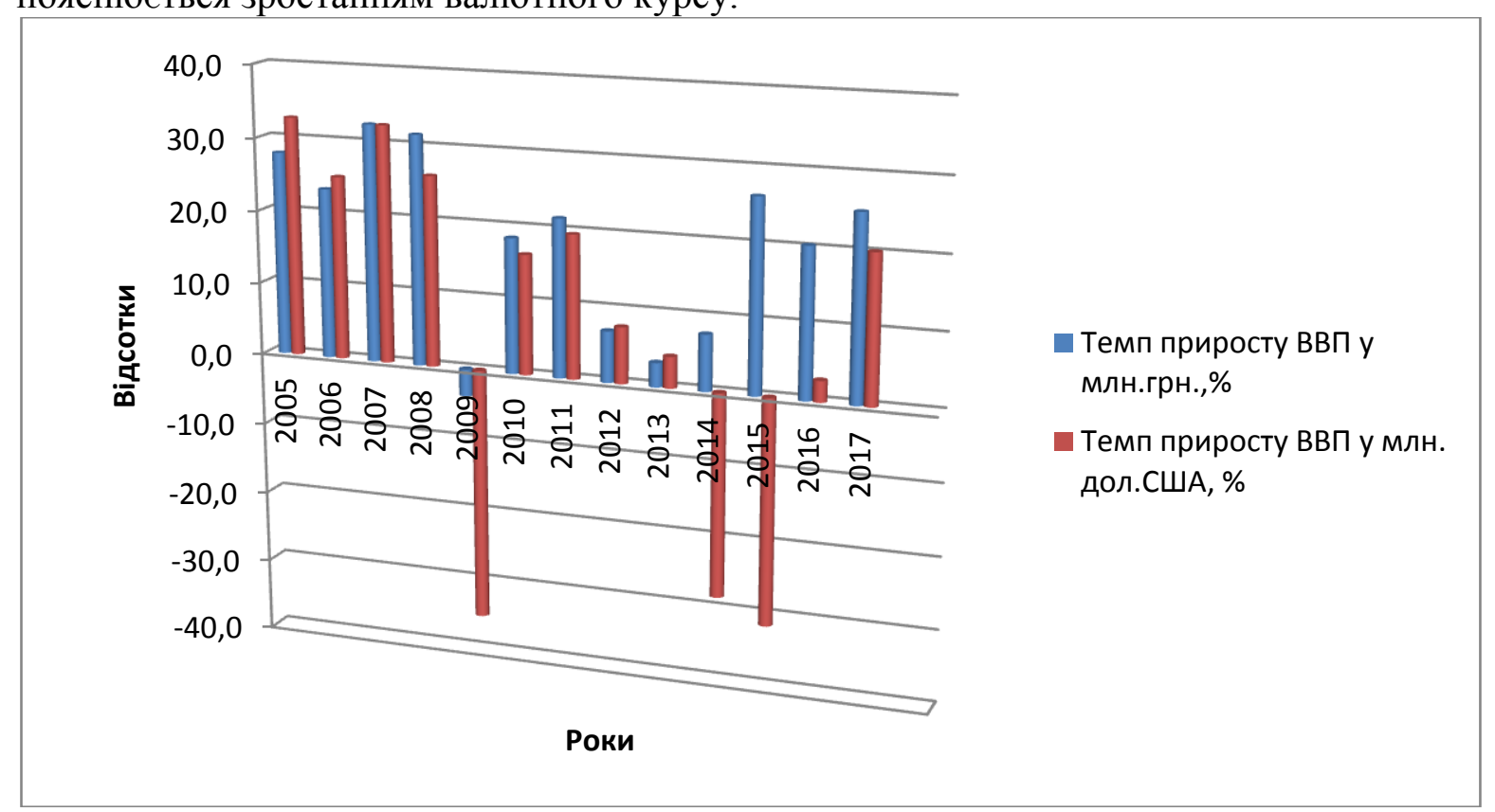

Puc.2. Темп приросту номінального ВВП за 2005-2017 pp.

Fig.2. Growth rate of nominal GDP for 2005-2017 
На мікроекономічному рівні управління інвестиційною діяльністю направлене на зростання рівня ефективності інвестиційної діяльності окремого суб'єкта господарювання. В той же час ефективність даної діяльності прямо залежить від сприятливого інвестиційного клімату та макроекономічного регулювання в умовах децентралізації.

Суб’єкт господарювання, стикаючись з різними аспектами інвестування, вирішує низку завдань: розробити інвестиційну стратегію підприємства, вибрати форми та об'єкти інвестування, знайти джерела фінансування, вибрати інвесторів та учасників інвестиційного процесу, розробити, проаналізувати та оцінити інвестиційні проекти, здійснити контроль за результатами інвестиційної діяльності.

3 огляду на викладене вище, основним концептуальним підходом як щодо визначення поняття “розвиток інвестиційної діяльності підприємств”, так і щодо управління інвестиційним чинником розвитку є стратегічний підхід; який пов'язаний 3 визначенням мети та основних напрямів інвестування, створенням умов для активізації інвестиційних процесів [6, С.216].

Управління інвестиційною діяльністю господарюючого суб'єкта - це комплекс методів розробки й реалізації управлінських рішень, пов'язаних із здійсненням інвестиційної діяльності.

Основною метою управління інвестиційною діяльністю господарюючого суб'єкта в умовах децентралізації $є$ забезпечення ефективності інвестиційної діяльності в довгостроковому і короткостроковому періодах.

На нашу думку, важливими завданнями управління інвестиційною діяльністю підприємства на перспективу визначимо такі:

максимізація інвестиційного прибутку господарюючого суб'єкта;

мінімізація інвестиційного ризику суб'єкта господарювання;

пошук та реалізація векторів вдосконалювання інвестиційних процесів.

Управління інвестиційною діяльністю на господарюючого суб'єкта, iз врахуванням галузевих особливостей, має певні особливості:

1) тісний зв'язок із системою управління на підприємстві, який зумовлено тим, що управлінські рішення у сфері інвестицій завжди прямо чи побічно взаємозалежні із іншими видами діяльності підприємства (з виробничою, фінансовою, постачальницькою, збутовою діяльністю);

2) динамічний та комплексний характер - означає, що управлінські рішення в інвестиційній сфері повинні бути взаємозалежні між собою та не суперечити одне одному. Саме цей взаємозв'язок забезпечує комплексність і ефективність управління інвестиційною діяльністю на підприємстві. Високий динамізм внутрішніх інвестиційних процесів на підприємстві та зовнішніх умов здійснення інвестиційної діяльності потребує, щоб і управлінські рішення в цій сфері були динамічними для того, щоб можна було своєчасно та чітко відреагувати на зміну тих або інших параметрів інвестиційної діяльності [7, С.126].

Врахуванням вищенаведених особливостей дозволить нам скласти пазли дієвої систему управління інвестиційною діяльністю господарюючого суб'єкта.

Ефективне управління інвестиційною діяльністю підприємства забезпечується реалізацією основних принципів, що запропоновані [8, С. 111]. Необхідно доповнити перелік запропонованих принципів наступним: флексибілізація на стратегічні цілі. Враховуючи особливості розвитку економічної системи країни, перспективи розвитку регіону, пріоритетність галузі, значення окремого підприємства - він зіграє головну роль для кожного господарюючого суб'єкта. 
Запорукою прийняття ефективних управлінських рішень у сфері інвестицій $є$ раціональна організація управління інвестиційною діяльністю господарюючого суб'єкта.

У процесі управління інвестиційною діяльністю господарюючого суб'єкта необхідно дотримуватись такої послідовності:

1) визначення інвестиційних потреб на кожному конкретному етапі його розвитку;

2) пошук альтернативних проектів та взаємозамінних напрямів реалізації окремих інвестиційних потреб;

3) оцінювання інвестиційної привабливості окремих шляхів інвестиційної діяльності;

4) прийняття відповідних інвестиційних рішень для формування інвестиційної програми;

5) організація реалізації прийняття інвестиційних рішень;

6) контроль процесу реалізації прийнятих інвестиційних рішень;

7) моніторинг ефективності окремих інвестиційних рішень,

8) коригування інвестиційної програми при необхідності.

Досягнення високої ефективності управління інвестиційною діяльністю можливе за рахунок покращення інформаційної забезпеченості, стратегічного планування, оцінки організації, посилення контролю, постійного моніторингу інвестиційних проектів, здійснення фінансово-економічних розрахунків.

Інформаційну система управління інвестиціями представимо у вигляді показників, які необхідні для проведення аналізу та прийняття управлінських рішень.

Планування інвестиційної діяльності розпочнемо після того, як визначимо чи необхідно вкладати кошти у даний проект, чи достатній буде позитивний ефект для відшкодування збитків та отримання прибутку. Пріоритетне завдання полягає в розробці планів щодо забезпечення розвитку підприємства необхідними інвестиційними ресурсам, а також зростання ефективності цього виду діяльності у майбутньому.

До організаційного забезпечення входить певна сукупність структурних підрозділів підприємства, яка забезпечує розробку та прийняття рішень щодо управління інвестиційною діяльністю і несе за них повну відповідальність [9, с.90].

Значне місце у процесі управління інвестиційною діяльністю займає контроль. $€$ такі види контролю як поточний, оперативний і стратегічний.

Головні види моніторингу, що застосовуються при інвестуванні $є$ фінансовий, маркетинговий та технічний.

Управління інвестиційною діяльністю передбачає проведення фінансовоекономічних розрахунків за різні періоди, що мають зв'язок з грошовими потоками. Всі фінансово-економічні розрахунки мають враховувати темп інфляції, яка з знецінює вартість грошових коштів, що викликає необхідність реального відображення вартості інвестиційних активів й грошових потоків підприємства, 3 метою пошуку найвигіднішого проекту.

Дотримання вище перелічених принципів оцінювання ефективності інвестицій дасть змогу забезпечити високі темпи розвитку та позитивний фінансовий результат господарської діяльності.

Управління інвестиційною діяльністю підприємства - це не лише фінансування поточних інвестиційних потреб підприємства. На даний час все більше менеджерів надають пріоритетне значення формуванню перспективних векторів інвестиційної 
діяльності господарюючого суб’єкта, ефективним інструментом якого є стратегічне планування.

Висновки. Підсумовуючи вищесказане, незаперечним $є$ факт, що інвестиції $€$ ключовою детермінантою розвитку економічних явищ та процесів усіх господарюючих суб'єктів, а також фактором економічного зростання я на усіх рівнях: макроекономічному та мікроекономічному.

Нами проаналізовано динаміку номінального ВВП України у національній та іноземній валюті, визначено темпи приросту ВВП за 2005-2018 pp., розраховано частку валового нагромадження у структурі ВВП з ціллю прийняття стратегічних рішень щодо управління інвестиційною діяльністю в умовах децентралізації.

Аналітичний матеріал дозволяє наштовхує нас на висновки, про те, що номінальний ВВП має тенденцію до зростання, проте частка валового нагромадження у ВВП коливається від 14,1 \% до 28,2\% протягом аналізованого періоду, що свідчить про нестабільність.

Система управління інвестиційною діяльністю господарюючого суб'єкта буде ефективно функціонувати лише тоді, коли матимемо чітку організацію процесу управління інвестиційною діяльністю.

Перспективами управління інвестиційною діяльністю кожного господарюючого суб'єкта повинні стати наступні завдання: максимізувати інвестиційний прибуток господарюючого суб'єкта; мінімізувати інвестиційний ризик суб' єкта господарювання; знайти напрями покращення інвестиційних процесів.

Процес управління інвестиційною діяльністю господарюючого суб'єкта в умовах децентралізації повинен базуватися на певному механізмі, який поєднає елементи, що регулюють процес розробки та реалізації інвестиційних рішень.

1. Огляд економіки України 2017. Американська торговельна палата в Україні сайт. URL: http://www.chamber.ua/Content/Documents/-1635684409Country_Profile_2018_UA.pdf (дата зверення: 10.09.2019).

2. Пилипів Н.І., Ємець О. І. Сучасні підходи до управління інвестиційною діяльністю. Вісник Прикарпатського університету. Економіка. Вип. 13. 2018. С. 185-191.

3. Мінфін сайт. URL: https://index.minfin.com.ua/economy/gdp/2018 (дата зверення: 10.09.2019).

4. Про затвердження Методичних рекомендацій щодо складання рахунку капіталу за інституційними секторами економіки Держкомстат України. Наказ від 12.12.2008 № 498. URL: https://zakon.rada.gov.ua/rada/show/v0498202-

08/ed20081212/find?text=\%C2\%E0\%EB\%EE\%E2\%E5+\%ED\%E0\%E3\%F0\%EE\%EC\%E0\%E4\%E6\% $\mathrm{E} 5 \% \mathrm{ED} \% \mathrm{ED} \% \mathrm{FF}+\% \mathrm{EE} \% \mathrm{~F} 1 \% \mathrm{ED} \% \mathrm{EE} \% \mathrm{E} 2 \% \mathrm{ED} \% \mathrm{EE} \% \mathrm{E} 3 \% \mathrm{EE}+\% \mathrm{EA} \% \mathrm{E} 0 \mathrm{EF} \% \mathrm{~B} 3 \% \mathrm{~F} 2 \% \mathrm{E} 0 \mathrm{~EB} \% \mathrm{~F}$ 3 (дата зверення: 10.09.2019).

5. Світовий банк сайт. URL: http://www.worldbank.org (дата зверення: 10.09.2019).

6. Смець О.І. Концептуальні підходи до організації розвитку інвестиційної діяльності підприємств на засадах парадигми економічної безпеки. Вісник наиіонального університету «Львівська політехніка». Серія: менеджмент та підприємництво в Україні: етапи становлення і проблеми розвитку. № 875. 2017. С. 215-222.

7. Павлова Т. Управління інвестиційною діяльністю підприємства. Сектори економіки в процесі реалізації державної регіональної політики: Дванадияті регіональні та муніципальні читання : зб. матеріалів доп. міжнар. наук.-практ. конф. [Тернопіль-Збараж, 26-27 жовт. 2017 р.] / редкол. : М. М. Шкільняк, А. Ф. Мельник, Г. Л. Монастирський [та ін.] ; відп. за вип. М. М. Шкільняк. Тернопіль : СМП “Тайп”, 2017. Ч. II. С. 125-126. URL: http://dspace.tneu.edu.ua/handle/316497/24908 (дата зверення: 10.09.2019).

8. Новикова I. В. Теоретичні основи вартісно-орієнтованого управління інвестиційною діяльністю підприємства. Економіка та управління підприємствами машинобудівної галузі. 2012. №. 3. С. 106-116.

9. Яцик К. Управління інвестиційною діяльністю як передумова ефективного розвитку підприємства. Економічний $і$ соиіальний розвиток Украйни в ХХI столітті : національна ідентичність та тендениії глобалізації : зб. тез доп. ХІІІ Міжнар. наук.-практ. конф. молодих вчених [м. Тернопіль, 24-25 берез. 2016 р.] / редкол. : Л. П. Амбрик, В. А. Валігура, О. М. Войтенко [та ін.] ; відп. за вип. 
Т. Я. Маршалок. Тернопіль : ТНЕУ, 2016. С. 95-96. URL: http://dspace.tneu.edu.ua/handle/316497/3444 (дата зверення: 10.09.2019).

\title{
References
}

1. "Overview of the Ukrainian economy 2017." American Chamber of Commerce in Ukraine, www.chamber.ua/Content/Documents/-1635684409Country_Profile_2018_EN.pdf. Accessed 10 Sept. 2019

2. Pylypiv, N.I., and O. I. Yemets. "Modern approaches to management of investment activity." Visnyk Prykarpatskoho universytetu. Ekonomika, no.13. 2018, pp.185-191. Accessed 10 Sept. 2019

3. Ministry of Finance Website, index.minfin.com.ua/economy/gdp/2018. Accessed 10 Sept. 2019.

4. "On Approval of Methodological Recommendations on Capital Account Creation by Institutional Sectors of the Economy." Order of State Statistics Committee of Ukraine from 2008, Dec 12, 498. Verkhovna Rada Ukrainy, zakon.rada.gov.ua/rada/show/v049820208/ed20081212/find?text=\%C2\%E0\%EB\%EE\%E2\%E5+\%ED\%E0\%E3\%F0\%EE \% EC\% E0\% E4\% $\mathrm{E} 6 \% \mathrm{E} 5 \% \mathrm{ED} \% \mathrm{ED} \% \mathrm{FF}+\% \mathrm{EE} \% \mathrm{~F} 1 \% \mathrm{E} \% \mathrm{E} \% \mathrm{E} 2 \% \mathrm{E} \% \mathrm{E} \% \mathrm{E} 3 \% \mathrm{EA}+\% \mathrm{EA} \% \mathrm{E} 0 \% \mathrm{EF} \% \mathrm{~B} 3 \% \mathrm{~F} 2 \%$ E0\% EB\% F3. Accessed 10 Sept. 2019.

5. Svitovyy bank Website, www.worldbank.org. Accessed 10 Sept. 2019.

6. Yemets, O.I. "'Conceptual approaches to the organization of development of investment activity of enterprises on the principles of the paradigm of economic security.' Visnyk natsional'noho universytetu «L'vivs'ka politekhnika», no. 875, 2017, pp. 215-222.

7. Pavlova, T. "Management of investment activity of the enterprise." Sectors of the economy in the process of implementation of the state regional policy: Twelve regional and municipal readings: Colections of materials international sci. pract. conf, 2017, pp. 125-126.

8. Novykova, I. V. "Theoretical basis of value-oriented management of investment activity of the enterprise." Economics and management of enterprises of the machine-building industry, no.3, 2012, pp.106-116.

9. Yatsyk, K. "Investment activity management as a prerequisite for effective enterprise development." Economic and Social Development of Ukraine in the XXI Century: National Identity and Trends in Globalization. Collection of XIII International sci. pract. conf. young scientists, 2016, pp. 95-96.

\section{УДК 657.47}

doi: 10.15330/apred.1.15.68-79

\section{ФОРМУВАННЯ ВНУТРШШНЬОГОСПОДАРСЬКОӤ ЗВІТНОСТІ Кафка С. М. ПОДАЛЬШИХ ВИТРАТ НА ОСНОВНІ ЗАСОБИ ПІДПРИЕМСТВ НАФТОГАЗОВОГО КОМПЛЕКСУ}

\author{
Івано-Франківський національний технічний університет \\ нафти і газу, \\ Міністерство освіти і науки України, \\ вул. Карпатська, 15, м. Івано-Франківськ, \\ 76019, Україна, \\ тел.: 0342-72-71-17, \\ e-mail: Kafka@i.ua
}

\begin{abstract}
Анотація. Стаття спрямована на дослідження чинних підходів до обліку подальших витрат на основні засоби, оскільки вони не є однозначними і постійно змінюються внаслідок процесів, які відбувалися у правовому та економічному середовищі, але мають значний вплив на формування облікової інформації про основні засоби суб'єкта господарювання, його витрати, а в кінцевому результаті і на прибуток підприємства звітного періоду. Для підприємств нафтогазового комплексу питання організації бухгалтерського обліку операцій, пов'язаних з ремонтом та модернізацією необоротних матеріальних активів, актуальне з огляду на необхідність виконання робіт з їх поліпшення через значний знос та втрату початкових технічних характеристик в умовах конкурентного середовища. При існуючому порядку обліку навіть усунення незначних пошкоджень шляхом заміни дорого вартісних деталей може
\end{abstract}

